Egyptian Journal of Aquatic Biology \& Fisheries

Zoology Department, Faculty of Science,

Ain Shams University, Cairo, Egypt.

ISSN $1110-6131$

Vol. 24(7): 607 - 617 (2020)

www.ejabf.journals.ekb.eg

\title{
Genetic Analysis of Four Marine Fish Species of Family Mugilidae Using Molecular Markers
}

\author{
Ali H. Abu Almaaty*, Hala E. Abd-Alaty and Osama A. Abbas \\ Zoology Department, Faculty of Science, Port Said University, Port Said, Egypt. \\ *Corresponding Author: ali_zoology_2010@yahoo.com
}

\section{ARTICLE INFO}

Article History:

Received: Oct. 14, 2020

Accepted: Nov. 10, 2020

Online: Nov. 13, 2020

Keywords:

Mugilidae,

DNA,

SCoT-Primers,

SDS-PAGE,

Polymorphism.

\begin{abstract}
Genetic differentiation and protein analysis of four fish species of family Mugilidae (Mugil cephalus, Mugil capito, Mugil auratus and Liza seheli), collected from the Mediterranean Sea in Port Said in Egypt, were studied using start codon targeted technique (SCoT) and Sodium dodecyl sulfate polyacrylamide gel electrophoresis (SDS-PAGE). In SCoT technique, eleven SCoT primers (SCoT-1, SCoT-2, SCoT-3, SCoT-4, SCoT-5, SCoT6, SCoT-21, SCoT-22, SCoT-28, SCoT-35 and SCoT-41) were used and different lengths of amplicons were generated ranging from $170 \mathrm{bp}$ with primers SCoT-3 and SCoT-6 to $1600 \mathrm{bp}$ with primer SCoT-2. The polymorphism percent ranged from $14 \%$ with SCoT-4 primer to $78 \%$ with SCoT-28 primer. The genetic similarity was the highest $(80 \%)$ between Mugil capito and Liza seheli and between Mugil auratus and Liza seheli, and it was the lowest (74\%) between Mugil cephalus and Mugil capito and between Mugil cephalus and Mugil auratus. SDS-PAGE analysis generated a total of twenty four bands with molecular weight ranging from 19 to 200 KD. Twenty two monomorphic bands were produced and only two polymorphic bands were generated. Twenty three bands were obtained from each species.
\end{abstract}

\section{INTRODUCTION}

Teleost species form the largest category among vertebrate animals. Wright $\boldsymbol{e t}$ al., (2003) speculated that the diversity of species results from productivity of available energy in a certain region. If energy is absent in a region (e.g., low availability of food in the desert), species richness will be low. Ricklefs, (2004) suggested that mutualism and competition between species control species abundance. However, in the case of fishes, MacArthur's, 1969 hypothesis is the most probable where he suggested that the diversity of species is accelerated if there are more areas to host suitable habitats.

Fishes include Agnatha, Chondrichthyes, Actinopterygii (ray-finned fishes) and Sarcopterygii (lobe-finned fishes). Most researchers are studying fishes as a food source and they work for enriching the body of aquaculture knowledge, also there are some interesting in their functional physiology, diversity, ecology and distribution patterns. Recently, there has been a wide interest in molecular structure of fishes (Wong, et al., 
2011; Pereira, et al., 2013; Rakshit, et al., 2015; Quraishia, et al., 2015). Correspondingly, the study of fish has expanded exponentially, and ichthyology is often sought to participate too many other fields of studies (Padilla and Williams, 2004; Lauder, et al., 2007; Feist and Longshaw, 2008). Generally, species is the important unit in these studies and taxonomy is the tool to prevent confusion and misinterpretation.

Molecular markers are used in genetic diversity assessment; this occurs at a wide range starting from level of nucleotide (SNPs) to gene and frequencies of allele (genotype information). They are also used in solving taxonomic problems, studying population structure and assigning species to their original taxonomic hierarchies that are the bases for phylogenetic studies. Molecular markers are useful in prioritizing of programs of germplasm conservation and in germplasms authentication (Sarwat, et al., 2011). DNAbased markers can be classified as PCR based or hybridization based. In PCR based markers, primers are used in amplification of DNA sequences. The type of molecular marker that can be chosen by researchers depends on the objective of the research. Each type of molecular markers has advantages and disadvantages depending on many factors such as reproducibility, cost, genome coverage, Informativeness, robustness, amount and quality of DNA required (Sarwat, 2012).

With the development of DNA-based molecular markers; Start codon targeted (SCoT) marker was developed based on the conserved sequences that flank ATG start codon of genes. SCoT technique is characterized by simple primer design, simple operation, highly effective polymorphism, low cost and good reproducibility (Chen $\boldsymbol{e t}$ al., 2009). It also needs only a single primer that acts as both the reverse and the forward one (Collard and Mackill 2009).

Proteins are one of the major constituents of any living cell. They have an important role in regulation of water balance and metabolism. Proteins can be used as indicator for the health of the living organism. Development of many pathological conditions can be caused by protein dysfunction. Although proteins possess critical biological functions, biological catalysts known as enzymes attracted researchers' attention from the beginning of protein science; this is because of their dynamic and flexible nature (Uversky and Dunker, 2010). Muscle sarcoplasm contains soluble proteins that are easy to be extracted (Buth and Murphy, 1999). Assessment of polymorphism between fish species is commonly studied through electrophoresis of muscle protein (Haniffa, et al., 2014). Proteins in complex extracts are widely analyzed by SDS-PAGE (sodium dodecyl sulfate-polyacrylamide gel electrophoresis) which is first described by Laemmli, (1970).

The present study aims to evaluate the efficiency of start codon target (SCoT) marker in measuring the genetic diversity among fish species especially, the closely related one. Four fish species of family Mugilidae ((Mugil cephalus, Mugil capito, Mugil auratus and Liza seheli) from Mediterranean Sea, Port Said, Egypt were used in this study. Also, SDS-PAGE analysis was performed to indicate the protein bands of the muscle of the four fish species. 


\section{MATERIALS AND METHODS}

\section{Samples collection}

Samples of Four fish species of family Mugilidae (Mugil cephalus, Mugil capito, Mugil auratus and Liza seheli) were collected from Mediterranean Sea, Port Said, Egypt. Appropriate sizes of muscle tissues were obtained from the four fish species and were frozen at $-20^{\circ} \mathrm{C}$.

\section{DNA Extraction and SCoT Technique}

DNeasy Mini Kit (Qiagen) was used in DNA extraction from muscles of the four fish species. NanoDrop was used for measuring the genomic DNA concentration. PerkinElmer/GeneAmp® PCR System 9700 (PE Applied Biosystems) was used for performing PCR amplification. It was programmed to fulfill 40 cycles after an initial denaturation cycle for $5 \mathrm{~min}$ at $94^{\circ} \mathrm{C}$. Each cycle programed to three steps; a denaturation step for 1 min at $94{ }^{\circ} \mathrm{C}$, an annealing step for $1 \mathrm{~min}$ at $50{ }^{\circ} \mathrm{C}$, and an elongation step for $1.5 \mathrm{~min}$ at $72{ }^{\circ} \mathrm{C}$. A set of eleven SCoT primers were used in the detection of polymorphism as shown in Table (1). The amplification reaction was carried out in $25 \mu 1$ reaction volume containing 12.5 $\mu \mathrm{l}$ Master Mix, $2.5 \mu \mathrm{l}$ primer (10pcmol), $3 \mu \mathrm{l}$ template DNA (10ng) and $7 \mu \mathrm{l}$ $\mathrm{dH} 2 \mathrm{O}$.

\section{Detection of the PCR Products:}

$1.5 \%$ agarose gel with ethidium bromide was used for running the amplified products and the buffer used was1X TBE buffer; the run was at 95volts. UV light was used for visualizing PCR products and a Gel Documentation System (BIO-RAD 2000) was used for photographing.

\section{Data Analysis}

The banding patterns resulted by SCoT primers were compared to evaluate the genetic relatedness of fish samples under the study. Products of the amplification were scored as ' 1 ' for presence and ' 0 ' for absence of bands. The cluster analysis was made through the similarity matrix. The cluster analysis was used for organizing the resulted data into meaningful structures developing the taxonomies. The distances between accessions are showed by Dice coefficient through PAST program after each accession represented its own cluster.

\section{SDS-PAGE analysis}

Muscular proteins were separated based on their molecular weight by Sodium dodecyl sulfate polyacrylamide gel electrophoresis (SDS-PAGE). Proteins of muscle tissue were extracted according to Fadda et al., (1999).

One gram of muscular tissue was homogenized with $9 \mathrm{ml}$ PBS (phosphate buffer solution), and then the sample was centrifuged for $15 \mathrm{~min}$ at $10000 \mathrm{rpm} ; 4^{\circ} \mathrm{C}$. The supernatant contained proteins and was transferred to a clean Eppendorf. Treatment buffer (1\% SDS, $10 \%$ glycerol, $10 \mathrm{mM}$ Tris-HCL PH 6.8, 1mM EDTA, DTT (dithiolthreitor) and pinch of bromophenole blue) was added to the protein sample and boiled for $5 \mathrm{~min}$ at $90^{\circ} \mathrm{C}$. Protein solution and protein marker were loaded into polyacrylamide gel and the run was carried out at 100 volts in 1x Tris/glycine- SDSrunning buffer. After electrophoresis, staining of the gel was occurred using $50 \mathrm{ml}$ of staining solution ( $10 \%$ acetic acid, $0.125 \%$ coomassie blue R-250 and $50 \%$ methanol), and then gel was dried and photographed. SDS-PAGE was performed according to (Laemmli, 1970). Molecular weight of protein patterns was stated according to Weber et al. (1972). 
Table 1. The sequence of SCoT primers, A: Adenine, T: Thymine, G: Guanine, C: Cytosine

\begin{tabular}{|c|c|}
\hline Primer Name & Sequence \\
\hline SCoT-01 & 5'-ACGACATGGCGACCACGC-3' \\
\hline SCoT-02 & 5'-ACCATGGCTACCACCGGC-3' \\
\hline SCoT-03 & 5'-ACGACATGGCGACCCACA-3' \\
\hline SCoT-04 & 5'-ACCATGGCTACCACCGCA-3' \\
\hline SCoT-05 & 5'-CAATGGCTACCACTAGCG-3' \\
\hline SCoT-06 & 5'-CAATGGCTACCACTACAG -3' \\
\hline SCoT-21 & 5'-CCATGGCTACCACCGGCC-3' \\
\hline SCoT-22 & 5'-CCATGGCTACCACCGCAC-3' \\
\hline SCoT-28 & 5'-CAACAATGGCTACCACCA-3' \\
\hline SCoT-35 & 5'-AACCATGGCTACCACCAC-3' \\
\hline SCoT-41 & 5'-CAACAATGGCTACCAGCA-3' \\
\hline
\end{tabular}

\section{RESULTS}

\section{Start codon targeted analysis}

In this study, Mugil cephalus, Mugil capito, Mugil auratus and Liza seheli) of family Mugilidae were collected from Mediterranean Sea for studding the genetic variability between them by using eleven SCoT primers (SCoT-1, SCoT-2, SCoT-3, SCoT-4, SCoT-5, SCoT-6, SCoT-21, SCoT-22, SCoT-28, SCoT-35 and SCoT-41) as shown in table (1). All eleven primers generated strong amplification profiles with distinct bands that revealed DNA polymorphism between the four species under study. Gene profiler computer software program was used for analyzing the banding patterns of the DNA fragments as shown in (Figures1, 2, 3, 4 and 5). The eleven SCoT primers detected a total of 135 DNA fragments (Table 2), with an average of 10 fragments per primer. The total number of amplified fragments varied from 4 (SCoT-28) to 18 (SCoT6) primers. Of the 135 amplified bands, 57 were monomorphic bands, 52 polymorphic and 26 unique bands with polymorphism ranged from $14 \%$ to $78 \%$.

Following are the amplification results of the four fish species obtained by the examined primers:

\section{Mugil cephalus}

SCoT primers with this species produced different band patterns of 93 bands ranged in size from $170 \mathrm{bp}$ in the primer (SCoT-6) to $1600 \mathrm{bp}$ in (SCoT-2). The generated bands ranged in number from 5 in (SCoT-5) to 13 in (SCoT-2 and SCoT-3).

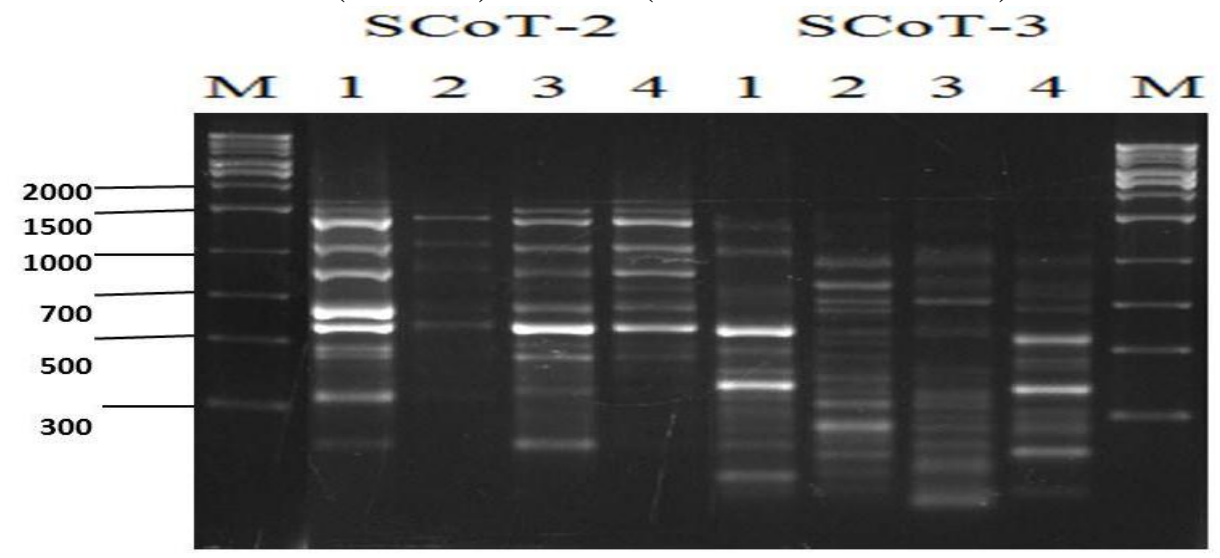

Fig. 1. SCoT profile of four fish species using SCoT primers: (SCoT-2 and SCoT-3). M refers to DNA marker (1-Mugil cephalus, 2-Mugil capito, 3-Mugil auratus and 4-Liza seheli). 
Table 2. Percentage of polymorphism, molecular weight and number of total bands, monomorphic bands, polymorphic and unique bands generated by eleven SCoT primers with four fish species (1-Mugil cephalus, 2-Mugil capito, 3-Mugil auratus and 4-Liza seheli).

\begin{tabular}{|c|c|c|c|c|c|c|c|c|c|c|c|}
\hline \multirow[t]{2}{*}{$\begin{array}{c}\text { Primer } \\
\text { code }\end{array}$} & \multicolumn{4}{|c|}{ No. of amplified bands } & \multirow{2}{*}{$\begin{array}{c}\text { Total } \\
\text { amplified } \\
\text { bands }\end{array}$} & \multirow{2}{*}{$\begin{array}{c}\text { Size of } \\
\text { amplified } \\
\text { bands }\end{array}$} & \multirow{2}{*}{ 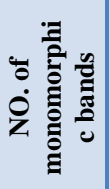 } & \multirow{2}{*}{ 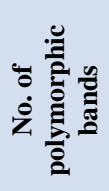 } & \multirow{2}{*}{$\begin{array}{l}\text { No. of } \\
\text { unique } \\
\text { bands }\end{array}$} & \multirow{2}{*}{ 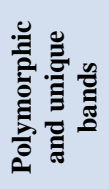 } & \multirow{2}{*}{ 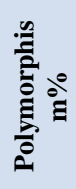 } \\
\hline & 1 & 2 & 3 & 4 & & & & & & & \\
\hline SCOT-1 & 7 & 7 & 8 & 8 & 9 & 180-500bP & 6 & 2 & 1 & 3 & $33 \%$ \\
\hline SCOT-2 & 13 & 9 & 13 & 13 & 15 & 250-1600bP & 9 & 4 & 2 & 6 & $40 \%$ \\
\hline SC0T-3 & 13 & 13 & 13 & 13 & 20 & 170-1400bp & 6 & 9 & 5 & 14 & $70 \%$ \\
\hline SCOT-4 & 7 & 6 & 7 & 7 & 7 & 200-520bp & 6 & 1 & $\mathbf{0}$ & 1 & $14 \%$ \\
\hline SCOT-5 & 5 & 7 & 7 & 6 & 10 & 250-750bp & 3 & 5 & 2 & 7 & $\mathbf{7 0 \%}$ \\
\hline SCOT-6 & 10 & 14 & 18 & 14 & 22 & 170-1300bp & 6 & 11 & 5 & 16 & $73 \%$ \\
\hline SCOT-21 & 7 & 10 & 8 & 8 & 14 & 200-900bp & 4 & 7 & 3 & 10 & $71 \%$ \\
\hline SCOT-22 & 9 & 8 & 6 & 7 & 9 & 220-700bp & 6 & 2 & 1 & 3 & $33 \%$ \\
\hline SCOT-28 & 8 & 5 & 5 & 4 & 9 & 200-750bp & 2 & 4 & 3 & 7 & $78 \%$ \\
\hline SCOT-35 & 7 & 10 & 9 & 5 & 13 & 200-900bP & 3 & 7 & 3 & 10 & $77 \%$ \\
\hline SCOT-41 & 7 & 6 & 6 & 6 & 7 & 250-750bp & 6 & $\mathbf{0}$ & 1 & 1 & $14 \%$ \\
\hline Total & 93 & 95 & 100 & 91 & 135 & 170-1600bp & 57 & 52 & 26 & 78 & $58 \%$ \\
\hline
\end{tabular}

\section{Mugil capito}

In this species, SCoT primers produced band patterns of 95 bands ranged in size from $180 \mathrm{bp}$ in the primers (SCoT-1 and SCoT-6) to $1400 \mathrm{bp}$ in (SCoT-2). The generated bands ranged in number from 5 in (SCoT-28) to 14 in (SCoT-6).
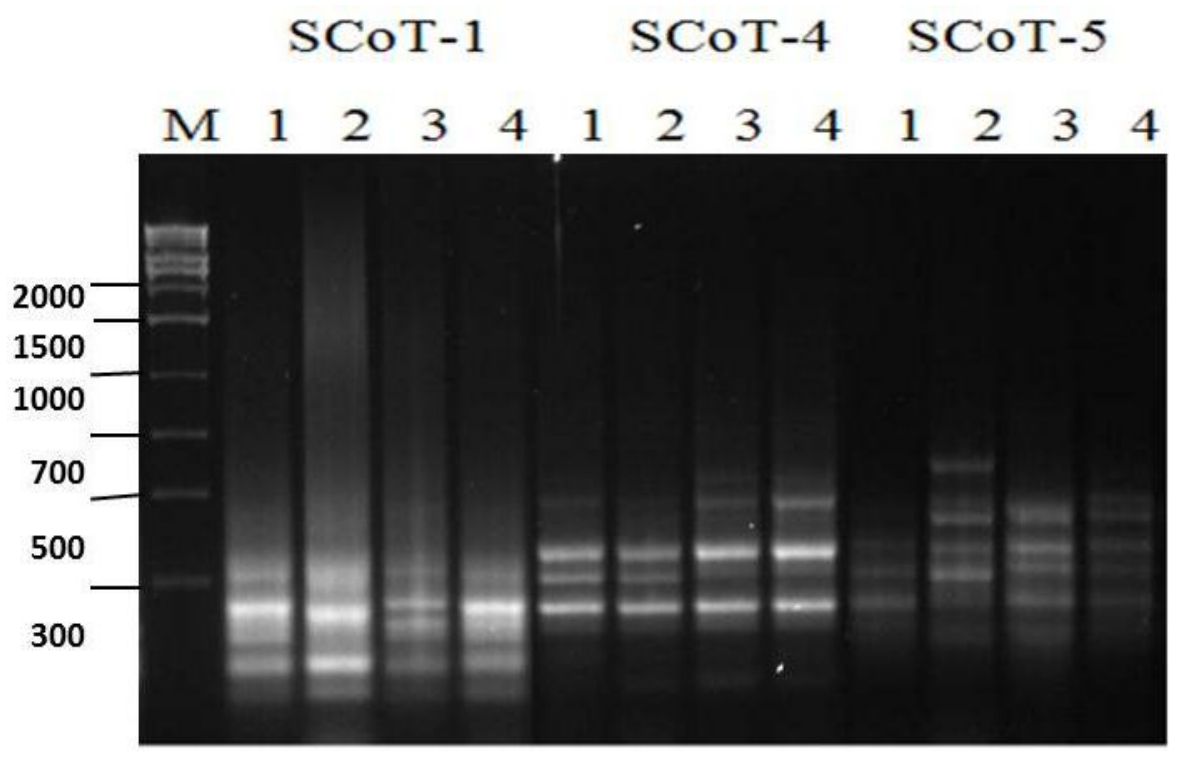

Fig. 2. SCoT profile of four fish species using SCoT primers: (SCoT-1, SCoT-4 and SCoT-5). M refers to DNA marker (1-Mugil cephalus, 2-Mugil capito, 3-Mugil auratus and 4-Liza seheli).

\section{Mugil auratus}

SCoT primers produced band patterns of 100 bands ranged in size from 170bp in the primers (SCoT-3 and SCoT-6) to $1500 \mathrm{bp}$ in (SCoT-2). The generated bands ranged in number from 5 in (SCoT-28) to 18 in (SCoT-6). 


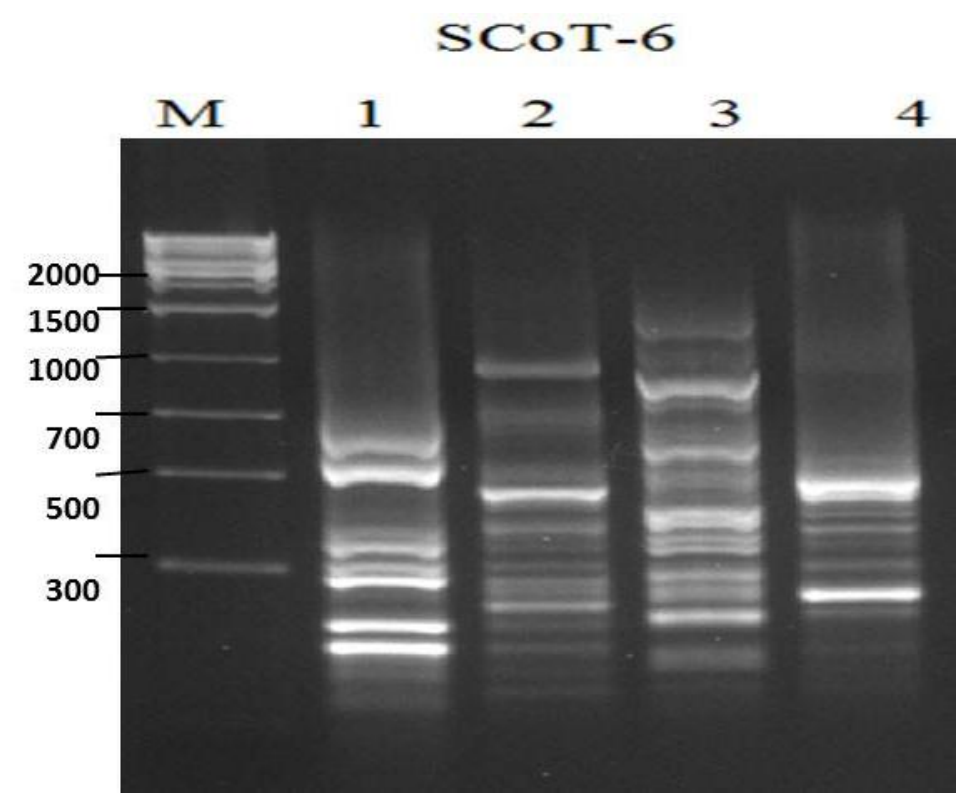

Fig. 3. SCoT profile of four fish species using SCoT primer (SCoT-6). M refers to DNA marker (1-Mugil cephalus, 2-Mugil capito, 3-Mugil auratus and 4-Liza seheli).

\section{Liza seheli}

Band patterns produced from SCoT primers were of 91 bands ranged in size from 180bp in the primers (SCoT-1 and SCoT-6) to $1600 \mathrm{bp}$ in (SCoT-2). The generated bands ranged in number from 4 in SCoT-28 to 14 in (SCoT-6).

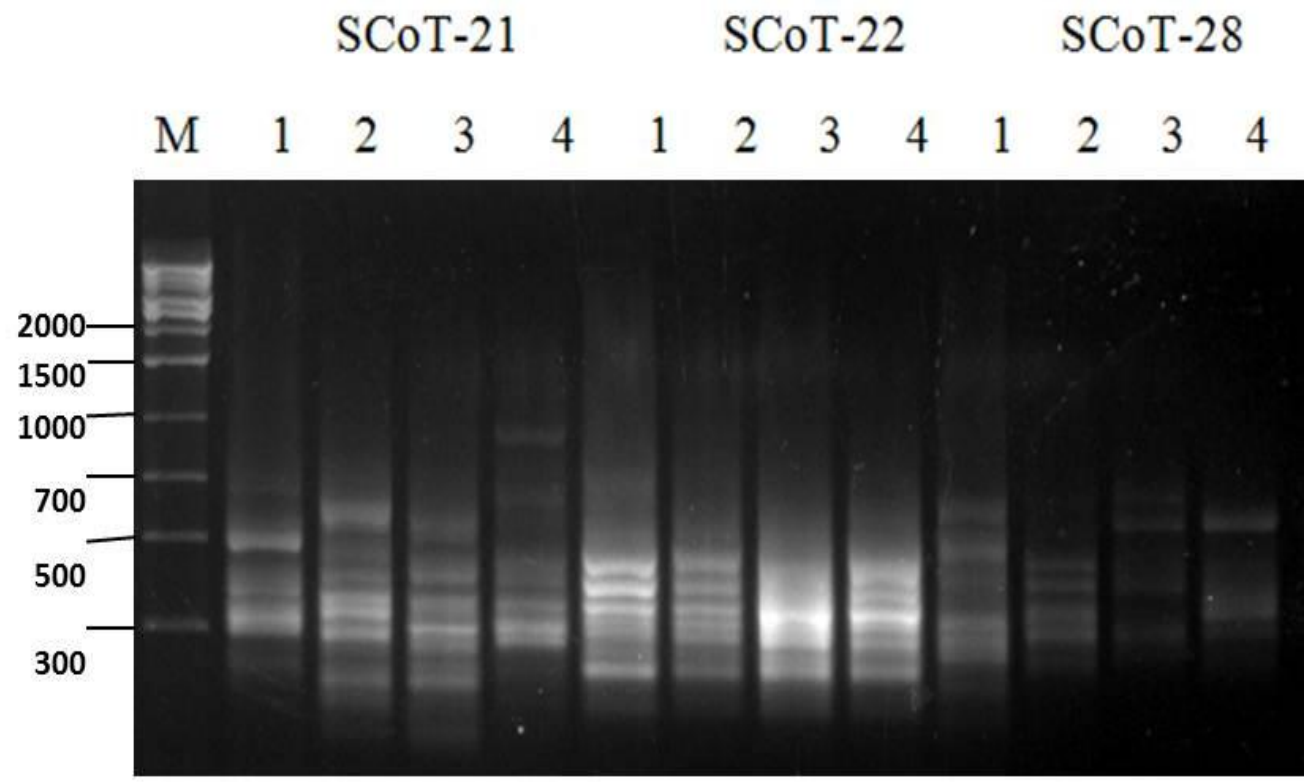

Fig. 4. SCoT profile of four fish species using SCoT primers (SCoT-21, SCoT-22 and SCoT-28). M refers to DNA marker (1-Mugil cephalus, 2-Mugil capito, 3-Mugil auratus and 4-Liza seheli). 


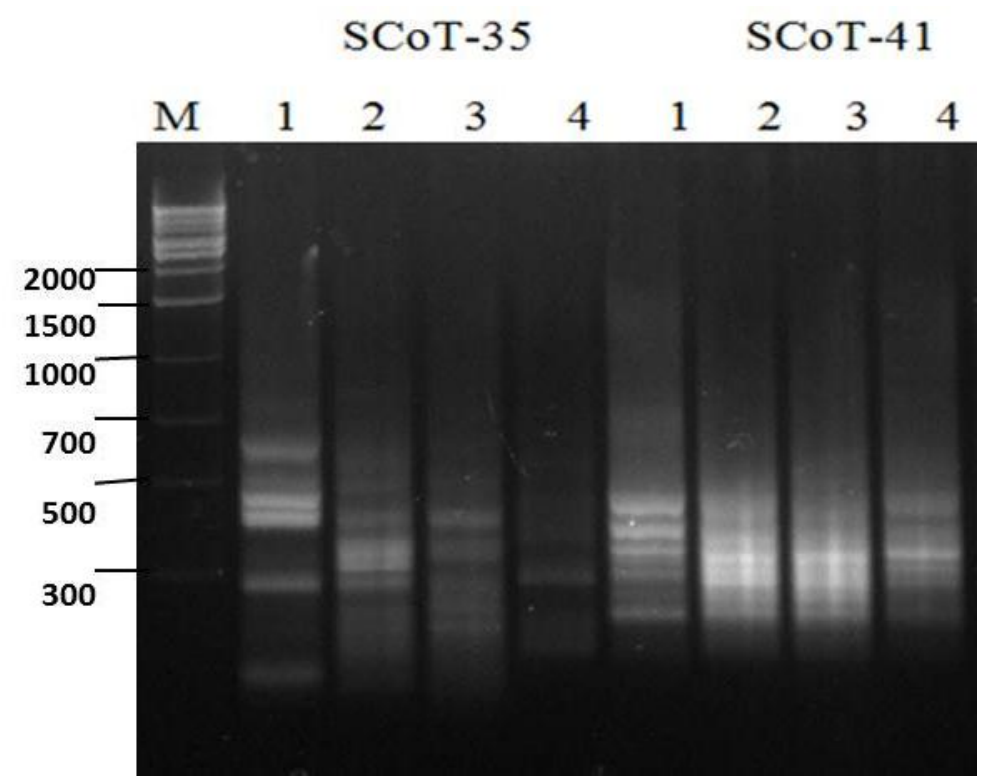

Fig. 5. SCoT profile of four fish species using SCoT primers (SCoT-35 and SCoT-41). M refers to DNA marker (1-Mugil cephalus, 2-Mugil capito, 3-Mugil auratus and 4-Liza seheli).

Genetic similarity was the highest between Mugil capito and Liza seheli and between Mugil auratus and Liza seheli, and the lowest was between Mugil cephalus and Mugil capito and between Mugil cephalus and Mugil auratus as shown in (Table 3) and (Figure 6).
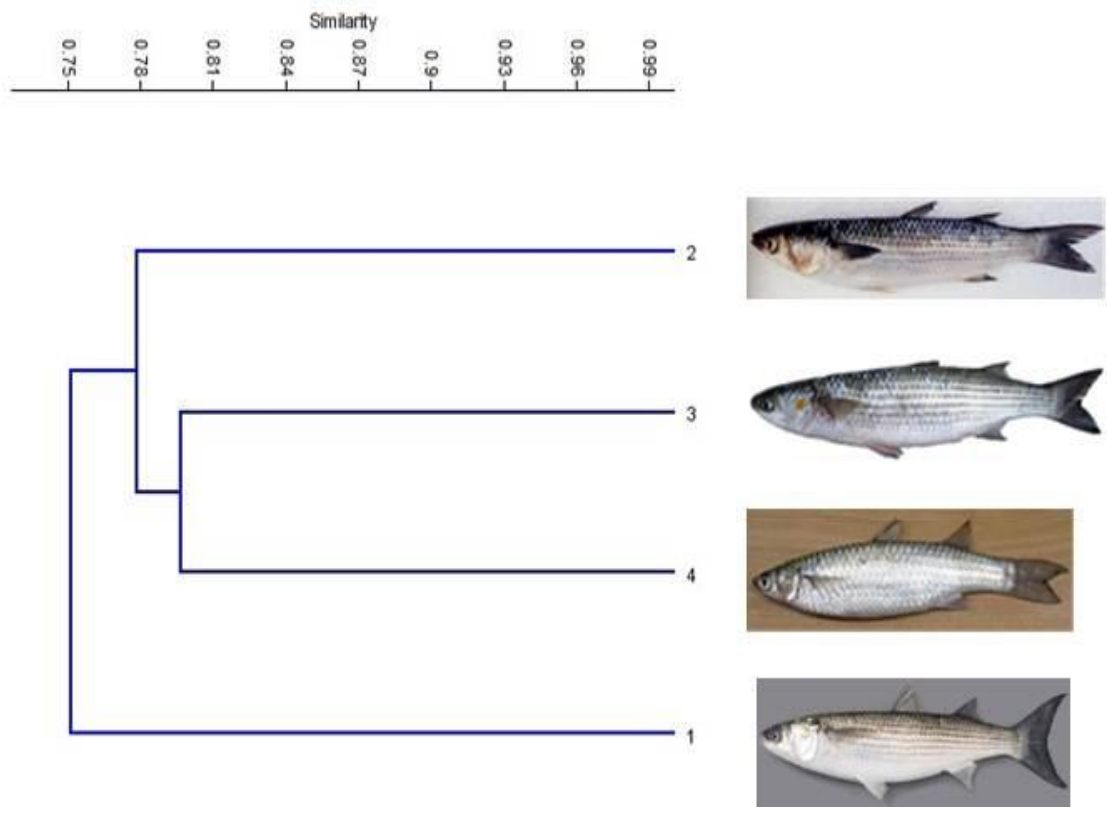

Fig. 6. Dendrogram showing Cluster analysis for four fish species (1-Mugil cephalus, 2-Mugil capito, 3Mugil auratus and 4-Liza seheli) based on SCoT molecular markers. 
Table 3. Averages of genetic similarities (\%) estimated by molecular SCOT primers, adopting the arithmetic complement of Jaccard coefficient for four fish species of Mugilidae. (1-Mugil cephalus, 2Mugil capito, 3-Mugil auratus and 4-Liza seheli).

\begin{tabular}{|c|c|c|c|c|}
\hline & 1 & 2 & 3 & 4 \\
\hline 1 & 100 & & & \\
\hline 2 & 74 & 100 & & \\
\hline 3 & 74 & 76 & 100 & \\
\hline 4 & 77 & 80 & 80 & 100 \\
\hline
\end{tabular}

\section{SDS-PAGE}

SDS-PAGE analysis generated a total of Twenty four bands with molecular weight ranging from 19 to 200 KD. 22 monomorphic bands were produced and only two polymorphic bands were generated with polymorphism $8.33 \%$. Twenty three bands were obtained from each species as illustrated in (Figure7) and ( Table 4).

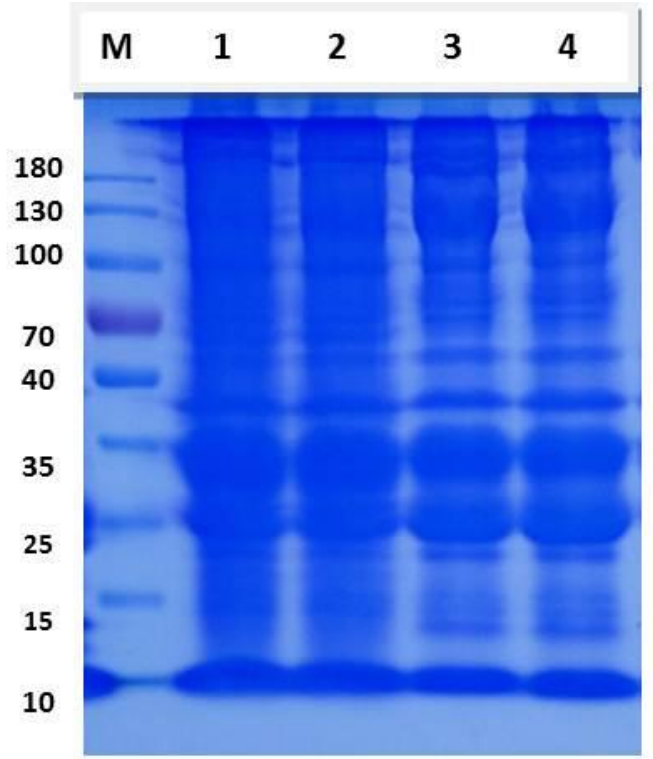

Fig. 7. Protein banding patterns of SDS-PAGE (1-Mugil cephalus, 2-Mugil capito, 3-Mugil auratus and 4Liza seheli). M refers to protein marker.

Table 4. Bands of SDS-PAGE protein of four fish species of Mugilidae; (1-Mugil cephalus, 2-Mugil capito, 3-Mugil auratus and 4-Liza seheli). MW refers to molecular weight.

\begin{tabular}{|l|l|l|l|l|}
\hline MW & $\mathbf{1}$ & $\mathbf{2}$ & $\mathbf{3}$ & $\mathbf{4}$ \\
\hline $\mathbf{2 0 0}$ & 1 & 1 & 1 & 1 \\
\hline $\mathbf{1 7 8}$ & 1 & 1 & 1 & 1 \\
\hline $\mathbf{1 6 9}$ & 1 & 1 & 1 & 1 \\
\hline $\mathbf{1 3 7}$ & 1 & 1 & 1 & 1 \\
\hline $\mathbf{1 2 7}$ & 1 & 1 & 1 & 1 \\
\hline $\mathbf{1 2 4}$ & 1 & 1 & 1 & 1 \\
\hline $\mathbf{1 0 9}$ & 1 & 1 & 1 & 1 \\
\hline $\mathbf{9 9}$ & 1 & 1 & 1 & 1 \\
\hline $\mathbf{9 2}$ & 1 & 1 & 1 & 1 \\
\hline $\mathbf{8 5}$ & 1 & 1 & 1 & 1 \\
\hline
\end{tabular}




\begin{tabular}{|l|l|l|l|l|}
\hline $\mathbf{7 9}$ & 1 & 1 & 1 & 1 \\
\hline $\mathbf{7 1}$ & 1 & 1 & 1 & 1 \\
\hline $\mathbf{5 9}$ & 1 & 1 & 1 & 1 \\
\hline $\mathbf{4 6}$ & 1 & 1 & 1 & 1 \\
\hline $\mathbf{4 2}$ & 1 & 1 & 1 & 1 \\
\hline $\mathbf{3 6}$ & 1 & 1 & 1 & 1 \\
\hline $\mathbf{3 3}$ & 1 & 1 & 1 & 1 \\
\hline $\mathbf{3 2}$ & 1 & 1 & 1 & 1 \\
\hline $\mathbf{3 0}$ & 1 & 1 & 1 & 1 \\
\hline $\mathbf{2 7}$ & 1 & 1 & 0 & 0 \\
\hline $\mathbf{2 6}$ & 1 & 1 & 1 & 1 \\
\hline $\mathbf{2 4}$ & 1 & 1 & 1 & 1 \\
\hline $\mathbf{2 2}$ & 0 & 0 & 1 & 1 \\
\hline $\mathbf{1 9}$ & 1 & 1 & 1 & 1 \\
\hline
\end{tabular}

\section{DISCUSSION}

SCoT (Start Codon Targeted) marker is a dominant and reproducible marker using a single primer in PCR (polymerase chain reaction) and depends on the short-conserved sequences that surround the ATG start (or initiation) codon (Collard and Mackill, 2009).

Xiong et al., (2011) mentioned that markers of SCoT are expected to be related to corresponding traits and functional genes, thus gene targeted marker system can be obtained from the amplicons. According to Mar'ie and Allam, (2017) there were not studies in polymorphism of fishes based on Start Codon Targeted technique; at least in Egypt. They began the investigation of the efficiency of this technique on tissues of fishes through estimation of relationship and genetic diversity among three of closely related species in family Carangidae (Caranx melampygus, Carangoides bajad and Caranx sexfasciatus collected from Red Sea of Hurghada, Egypt.

The genetic variation among three species of gastropods (Neverita josephinia, Hexaplex trunculus and Murex altispira) was evaluated by Abu Almaaty (2020) using SCoT marker and SDS-PAGE. Also, Abu-Almaaty et al., (2020a) have estimated the genetic relationship between two species of family Moronidae by using these techniques revealing their efficiency in measuring species polymorphism. SDS-PAGE was also used for assessment the genetic similarity and protein analysis of some cyprinid fish species (Abu Almaaty et al., 2017; 2020b).

This study differentiated among a very closely related four fish species of family Mugilidae by SCoT technique revealing that this technique can be used as an effective tool for molecular differentiation between closely related species. SDS-PAGE was also performed producing a total of 24 bands, 23 bands for each species.

\section{CONCLUSION}

The present study showed that start codon targeted markers are successful molecular tool that efficiently evaluates the genetic variation between the closely related fish species. Also, SDS-PAGE described the protein bands of the muscle of the four species.

\section{REFERENCES}

Abu-Almaaty, A. H. (2020). Potential of Start Codon Targeted (SCoT) Markers and SDS-PAGE to Estimate Genetic Diversity and Relationships among Three 
Gastropods Species from The Mediterranean Sea, Port Said, Egypt. Egyptian Journal of Aquatic Biology \& Fisheries. 24(7):133 - 143

Abu-Almaaty, A. H.; Abd-Alaty, H. E.; Abbas, O. A and Hassan, M. K. (2020a). Genetic Relationship Between Two Species of Genus Dicentrarchus Based on SCoT Markers and SDS-PAGE. Egyptian Journal of Aquatic Biology \& Fisheries. 24(5): $393-402$.

Abu-Almaaty A. H.; Bahgat, I. M. and Al-Tahr, Z. M. (2017b). Genetic variability of three fish species of genus Puntius. Journal of Experimental and Applied Animal Sciences, 2(2): 153-164.

Abu-Almaaty A. H.; Bahgat, I. M. and Al-Tahr, Z. M. (2020b). Using SDS-PAGE and ISSR as biochemical markers for assessment the genetic similarity and protein analysis of some Cyprinid fish species. - Genetika, 52(1): 161-175.

Buth, D. J. and Murphy, R. W. (1999). The use of isozyme characters in systematic studies. Bio Syst Ecol. 27: 117-129.

Chen, H.; He, X. H.; Luo, C.; Zhu, J. H. et al. (2009). The optimization of SCoT-PCR system of Longan (Dimocarpus longan). Genom. Appl. Biol. 28: 970-974.

Collard, B. C. Y. and Mackill, D. J. (2009). Start Codon Targeted (SCOT) Polymorphism: a simple novel DNA marker technique for generating gene-targeted markers in plants. Plant Mol. Biol. Rep. 27: 86-93.

Fadda, S.; Sanz, Y.; Vignolo, G.; Aristoy, M. C.; Oliver, G. and Toldra, F. (1999). Characterization of muscle sarcoplasmic and myofibrillar protein hydrolysis caused by Lactobacillus plantarum. Appl. Environ. Microbiol. 65: 3540-3546.

Feist, S. W. and Longshaw, M. (2008). Histopathology of fish parasite infectionsImportance for populations. Journal of Fish Biology. 73: 2143- 2160.

Haniffa, M. A.; Jeya Sheela, P.; James Milton, M.; Kavitha, K.; Bhat, A. A. and Chelliah, A. (2014). Morphometric, meristic and Haniff marker systems for species identification and evolutionary analysis in five Indian Channids. Biochem. Syst. Ecol. 55: 131-136.

Laemmli, U. K. (1970). Cleavage of structural proteins during the assembly of the head of bacteriophage T4. Nature. 227: 680-685.

Lauder, G. V.; Anderson, E. J.; Tangorra, J. and Madden, P. G. A. (2007). Fish biorobotics: kinematics and hydrodynamics of self-propulsion. The Journal of Experimental Biology. 210: 2767-2780.

MacArthur, R. H. (1969). Patterns of communities in the tropics. Biological Journal of the Linnean Society. 1: 1930.

Mar'ie, Z. A. and Allam, M. (2017). Using start codon targeted (SCoT) polymorphism for genetic diversity analysis of three Red Sea fishes (Family: Carangidae). IOSR Journal of Pharmacy and Biological Sciences. 12: 50-56.

Padilla, D. K. and Williams, S. L. (2004). Beyond ballast water: aquarium and ornamental trades as sources of invasive species in aquatic ecosystems. Frontiers in Ecology and the Environment. 2(3): 131-138.

Pereira, L. H. G.; Hanner, R.; Foresti, F. and Oliveira, C. (2013). Can DNA barcoding accurately discriminate megadiverse Neotropical freshwater fish fauna?. BMC Genetics. 14(20): 114.

Rakshit, A.; Paul, A.; Bhattacharjee, S.; Banik, T.; Saran, R.; Mandal, B.; Poddar, D. and Gangopadhyay, K. (2015). Cytogenetic and molecular profiling of spotted 
snake head fish Channa punctatus (Bloch, 1793) from three districts (Nadia, Hooghly and north 24 Parganas) of west Bengal, India. International Journal of Fisheries and Aquatic Studies. 3(1): 312-319.

Ricklefs, R. E. (2004). A comprehensive framework for global patterns in biodiversity. Ecology Letters. 7: 1-15.

Sarwat, M.; Nabi, G.; Das, S. and Srivastava, P. S. (2011). Molecular Markers in Medicinal Plant Biotechnology: Past and Present. Critical Rev Biotech (In press). doi: $10.3109 / 07388551$.

Sarwat, M. (2012). Plant DNA Fingerprinting and Barcoding: Methods and Protocols, Methods in Molecular Biology. Springer Science+Business Media. 862. DOI 10.1007/978-1-61779-609-8-9.

Quraishia, S. F.; Panneerchelvam, S.; Zainuddin, Z. and Rashid, N. H. A. (2015). Molecular Characterization of Malaysian Marine Fish Species using Partial Sequence of Mitochondrial DNA 12S and 16S rRNA Markers. Sains Malaysiana. 44(8): 1119- 1123.

Uversky, V. N. and Dunker, A. K. (2010). Understanding protein non-folding. Biochim. Biophys. Acta. 1804(6): 1231-1264.

Wong, L. L.; Peatman, E.; Lu, J.; Kucuktas, H.; He, S.; Zhou, C. J.; Nanakorn, U. and Liu, Z. J. (2011). DNA barcoding of catfish: Species authentication and phylogenetic assessment. PLoS ONE. 6(3): e17812.

Wright, S.; Gray, R. D. and Gardner, R. C. (2003). Energy and the rate of evolution: inferences from plant rDNA substitution rates in the western Pacific. Evolution. 57: 2893-2898.

Xiong, F.; Zhong, R.; Han, Z.; Jiang, J.; He, L.; Zhuang, W. and Tang R. (2011). Start Codon Targeted polymorphism for evaluton of functional genetic variation and relationships in cultivated peanut (Arachs hypogaeal L.). Genotypes. Mol. Biol. Rep. 38(5): 3487-3494.

Weber, K.; Pringle, J. R. and Osborn, M. (1972). Measurement of molecular weights by electrophoresis on SDS-acrylamide gel. Methods in enzymology. 26: 3-27. 